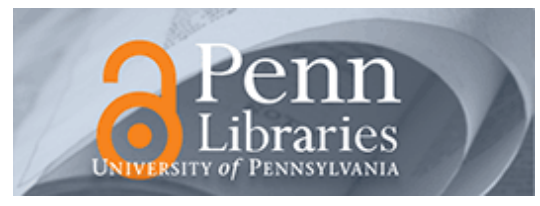

University of Pennsylvania

ScholarlyCommons

Management Papers

Wharton Faculty Research

$3-2013$

\title{
Coordinating and Competing in Ecosystems: How Organizational Forms Shape New Technology Investments
}

Rahul Kapoor

University of Pennsylvania

Joon Mahn Lee

Follow this and additional works at: https://repository.upenn.edu/mgmt_papers

Part of the Business Administration, Management, and Operations Commons

\section{Recommended Citation}

Kapoor, R., \& Lee, J. (2013). Coordinating and Competing in Ecosystems: How Organizational Forms Shape New Technology Investments. Strategic Management Journal, 34 (3), 274-296. http://dx.doi.org/ 10.1002/smj.2010

This paper is posted at ScholarlyCommons. https://repository.upenn.edu/mgmt_papers/42

For more information, please contact repository@pobox.upenn.edu. 


\title{
Coordinating and Competing in Ecosystems: How Organizational Forms Shape New Technology Investments
}

\author{
Abstract \\ We consider firms in the context of their business ecosystems and explore how differences in the ways in \\ which firms are organized with respect to complementary activities affect their decision to invest in new \\ technologies. We argue that, in addition to creating differences in incentives and bureaucratic costs, firm- \\ complementor organizational form plays an important role in the firm's ability to coordinate \\ accompanying changes in complementary activities so as to shape the benefits from investing early in \\ the new technology. We test our predictions in the U.S. healthcare industry from 1995-2006. The study \\ makes a strong case for viewing firms' competitive strategies in the context of their business ecosystems \\ and for the existence of an important link between firms' coordination choices and their strategic \\ investments.

\section{Keywords} \\ firm boundaries, technology investment, business ecosystem, complementors, alliances

\section{Disciplines} \\ Business Administration, Management, and Operations
}




\title{
Coordinating and Competing in Ecosystems: How Organizational Forms Shape New Technology Investments
}

\author{
Rahul Kapoor \\ The Wharton School \\ University of Pennsylvania \\ Philadelphia, PA 19104 \\ Tel: 12158986458 \\ Email: kapoorr@wharton.upenn.edu \\ Joon Mahn Lee \\ The Wharton School \\ University of Pennsylvania \\ Philadelphia, PA 19104 \\ Tel: 12158961981 \\ Email: joonmahn@wharton.upenn.edu
}

August 16, 2010

\begin{abstract}
We consider firms in the context of their business ecosystems and explore how governance choices with respect to complementors and distributors shape their competitive behavior-i.e., investments in new technologies. We argue that, in addition to creating differences in incentives, governance choices play an important role in the firm's ability to coordinate accompanying changes in interdependent activities so as to create value from the new technology. We test our predictions in the U.S. healthcare industry from 1995-2006. We examine how hospitals' decisions to invest in new imaging technologies are shaped by their governance modes with physicians - key complementors to hospitals, and with managed care organizations (MCOs) primary distributors of hospital and physician services. We find that hospitals pursuing alliances with physicians are more likely to invest in new technologies than hospitals pursuing arm'slength or integrated modes, and the likelihood of investment is increasing in the scope of alliance. Finally, hospitals pursuing tapered integration with downstream MCOs are more likely to invest in new technologies than hospitals pursuing arm's-length relationships. Overall, the study argues for extending research on organizational forms to explore the link between coordination mechanisms and competitive behavior, and to consider such choices in the context of business ecosystems.
\end{abstract}

We thank Matthew Bidwell, Rob Burns, Olivier Chatain, Guy David, JP Eggers, Gabriel Natividad, Anne Parmigiani, Jason Snyder, John Kimberly, Neerav Mehta, Ethan Mollick, Felipe Monteiro, Evan Rawley, Lori Rosenkopf, Harbir Singh and participants at ACAC 2010 for helpful comments. All remaining errors are ours. 


\section{INTRODUCTION}

Scholars in management have shed light on a variety of organizational forms that firms use to manage interdependent activities, being explicit about the tradeoffs associated with the different modes of organization (e.g., Dyer and Singh, 1998; Harrigan, 1984; Hennart, 1993; Mahoney, 1992; Williamson, 1991a). A large number of empirical studies have examined the drivers and performance implications of firms' governance choices. However, the literature has been surprisingly silent on how such choices shape firms' strategic behavior, an important precursor to firms' performance. Notable exceptions are Armour and Teece (1980), who examined how vertical integration affects firms' investments in R\&D, and Mullainathan and

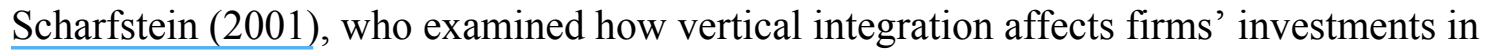
production capacity.

An emergent perspective in strategy views a firm's ability to create and appropriate value in the context of its business ecosystem encompassing interdependent activities and value chains (Brandenburger and Nalebuff, 1998; Porter, 1998; Teece, 2007). Ecosystems are characterized by joint value creation and appropriation among buyers, suppliers, and complementors. The choice of a firm's organizational form with respect to activities in the ecosystem is among the most important choices faced by managers (Iansiti and Levien, 2004; Moore, 1996). However, scholars have yet to systematically explore the implications of organizational forms in the context of business ecosystems.

In this study, we consider firms' governance choices with respect to activities in the ecosystem and explore how such choices shape an important type of strategic behavior - i.e., investments in new technologies (e.g., Mitchell, 1989; Mitchell and Singh, 1992). We suggest that a firm's ability to create value from a new technology may depend in part on the accompanying changes by actors in the ecosystem, who may need to adapt in order for the new 
technology to be successfully commercialized (Adner and Kapoor, 2010; Argyres, 1995;

Rosenberg, 1976; Teece, 2007). In addition, a firm's ability to appropriate value from the new technology will depend on its relative bargaining power over other players in the ecosystem (Brandenburger and Nalebuff, 1998; Porter, 1980). Drawing on organizational economics and strategy literatures, we argue that a firm's governance mode plays an important role in this coordinated adaptation for value creation and competition for value capture. Hence, governance mode is important to the firm's decision to undertake such strategic investments. Our empirical context allows us to examine a variety of organizational forms: arm's-length relationships, hierarchies, and hybrid arrangements such as alliances (Dyer and Singh, 1998; Kogut, 1988) and tapered integration (Harrigan, 1984, 1986). In so doing, we are able to explicitly consider tradeoffs that firms face with respect to the different forms of organization.

The context for the study is the U.S. health care industry from 1995 to 2006 . We focus on three main players that constitute the delivery of health care services - hospitals, physicians, and managed care organizations (MCOs). Each of these player's abilities to create and appropriate value from its own resources and capabilities is critically dependent on the other players. However, the nature of interdependence between hospitals and physicians is distinct from the nature of interdependence between hospitals and MCOs. On the one hand, while hospitals provide facilities and staff to diagnose and treat the patients, the physicians are the primary source of medical expertise for the diagnosis and the treatment. The service provided by the physicians is a complement to the service provided by the hospitals, and hence physicians are key complementors to the hospitals (Brandenburger and Nalebuff, 1998: 12). On the other hand, hospitals' (and physicians') services are packaged and distributed by MCOs downstream as health plans. Hence, while the hospital-physician relationship corresponds to a firm- 
complementor relationship, the hospital-MCO relationship corresponds to a firm-buyer relationship.

We examine a hospital's decision to invest in new medical imaging technologies, one of the critical technological advances that have characterized the health care industry (Burns et al., 2000). We focus on two distinct imaging technologies: positron emission tomography (PET) and magnetic resonance imaging (MRI), which have emerged at different periods in the industry. We find that hospitals pursuing alliances with physicians are more likely to invest in new imaging technologies than hospitals that either have an arm's-length relationship or are integrated and employ their own physicians. Among hospitals pursuing alliances, the likelihood of investment in new imaging technologies is increasing in the scope of the alliance. Finally, hospitals pursuing tapered integration with MCOs such that they use both internal and external buyers are more likely to invest in new technologies than hospitals pursuing only arm's-length relationships.

The results from the study, while limited to a single industry, speak to a few important issues in the strategy literature. First, the study contributes to research on firm boundaries by exploring the link between organizational forms and strategic behavior. We argue and show that when the value created by a firm's strategic investment is dependent on accompanying changes among activities in the ecosystem, the firm's governance choices with respect to those activities will have an important bearing on its ability to coordinate such changes and, hence, on its decision to undertake such strategic investments. The finding that hospitals pursuing strategic alliances with physicians are more likely to invest in new imaging technologies than hospitals pursuing integrated strategies reaffirms the need to consider both the costs and the benefits of integration (e.g., Gibbons, 2005). While integration provides control over complementary activities and may improve coordination among such activities, it may suffer from reduced 
incentives, bureaucratic costs, and influence activities (e.g., Grossman and Hart, 1986; Hart and Moore, 1990; Milgrom and Roberts, 1992; Williamson, 1975, 1985). Hence, firms may need to consider tradeoffs regarding ownership of complementary activities, and evaluate alternative hybrid forms that may preserve incentives while allowing for coordinated adaptation (Williamson, 1991a). Beyond value creation, we also argue that governance choices may influence firms' bargaining power over other players in the ecosystem and shape value appropriation from new technology investments (Harrigan, 1984; Porter, 1980). This effect was most evident from our finding that hospitals pursuing tapered integration with respect to MCOs were more likely to invest in new technologies than hospitals pursuing market-based contracting.

Second, to the best of our knowledge, we believe that ours is the first study in the strategy literature that has explicitly considered complementors in examining different types of organizational forms and their strategic implications on focal firms. While complements are an important part of the firm's business environment (Brandenburger and Nalebuff; 1998, Moore, 1993; Porter, 1998; Teece, 2007), surprisingly little systematic research has been done to examine their interaction with firm strategies and outcomes. ${ }^{1}$ We hope that our findings will encourage scholars to expand their analysis of organizational forms from activities in the vertical chain to also consider complements, so as to develop a better understanding of firm strategies in the context of the business ecosystem.

Third, our result regarding hospitals being more likely to invest in new technologies when their alliances with physicians are characterized by broader scope suggests that alliance "design choices" among complementors may have important implications for inter-firm coordination. Scholars analyzing inter-firm alliances and alliance portfolios within a business

\footnotetext{
${ }^{1}$ Notable exceptions include Gawer and Henderson (2007), Pierce (2009), Ozcan and Eisenhardt (2009) and Adner and Kapoor (2010).
} 
ecosystem may build on these findings to explore how the design of the alliance rather than its existence per se shapes firms' value creation and appropriation (Aggarwal, Siggelkow and Singh, Forthcoming; Agarwal, Croson, and Mahoney, 2010; Khanna, Gulati, and Nohria, 1998).

Finally, we contribute to the literature on technology adoption by showing that a firm's organizational form with respect to activities in the ecosystem has a significant effect on its decision to adopt a new technology. Hence, we add to the factors considered by the adoption literature (e.g., Geroski, 2000; Griliches, 1957; Rogers, 1995) by suggesting that the distribution of organizational forms in a given industry plays an important role in explaining the pattern of new technology adoption.

\section{THEORY AND HYPOTHESES}

Faced with the opportunity of investing in new technologies, firms face important tradeoffs (e.g., Lieberman and Montgomery, 1988; Mitchell, 1989; Mitchell and Singh, 1992). On the one hand, investing in the new technology may allow a firm to assert its technology leadership and create competitive advantage. On the other hand, given the technological and market uncertainty, investing in a new technology may also expose a firm to significant financial risk of whether it can profit from the new technology.

How does a firm's organizational form with respect to activities in the ecosystem affect its propensity to undertake new technology investments? We explore this question by drawing on arguments from organizational economics and strategy literatures (e.g., Dyer and Singh, 1998; Gibbons, 2005; Harrigan, 1984; Williamson, 1985, 1991). We create our hypotheses in the context of a simple ecosystem comprising three distinct activities: a focal activity, a complementary activity, and a downstream buying activity. Hence, the ecosystem comprises 
focal firms, their key complementors, and downstream buyers. Formally, we follow Brandenburger and Nalebuff (1998) in defining a player as a complementor if buyers value the focal firm's product more when they have the other player's product than when they have the firm's product alone (p. 18). For example, manufacturers of hardware and developers of content or software are complementors to each other. A similar relationship also exists between providers of online services and payment gateways. We first consider governance choices between firms and their complementors. We then consider governance choices between firms and their downstream buyers.

\section{Organization of Firms and Complementors}

The literature in organizational economics has suggested some important tradeoffs that exist between the market and hierarchy forms of organization These tradeoffs can be broadly categorized along the dimensions of "cost of organization" and "adaptability of organization" (e.g., Gibbons, 2005; Williamson, 1991a). The cost of a given organizational form entails the intensity of incentives for the respective parties (Grossman and Hart, 1986; Hart and Moore, 1990), the bureaucratic costs associated with governance and decision-making (Williamson, 1975, 1985), and the influence activities in which parties attempt to influence decisions or the allocation of resources towards their personal gain (Milgrom and Roberts, 1992). Adaptability refers to the extent to which two parties can generate a coordinated response to changing market and technological circumstances characterized by high levels of uncertainty (Barnard, 1938; Williamson, 1991a; 1991b). ${ }^{2}$ On the one hand, while hierarchy enjoys superiority in adaptability, it suffers from a high cost of organization. On the other hand, while market provides high-

\footnotetext{
${ }^{2}$ We note that our treatment of the "cost of organization" excludes transaction costs which we explicitly consider within the category of "adaptability of organization."
} 
powered incentives and is not subject to bureaucratic costs or influence activities, it suffers from limited adaptability.

The alliance form of organization exhibits characteristics of a hybrid between markets and hierarchies (Borys and Jemison, 1989; Dyer and Singh, 1998; Menard, 2004; Williamson, 1991a). It provides greater incentives than hierarchies, as partners retain autonomy over their tasks and the associated payoffs. It also enables greater adaptability than markets, as cooperating partners develop communication channels and codes to facilitate knowledge sharing and coordination of interdependent tasks (Doz, 1996; Dyer and Nobeoka, 2000; Dyer and Singh, 1998; Gulati and Singh, 1998; Gulati, Lawrence, and Puranam, 2005; Zollo et al., 2002). Successful commercialization of a new technology often requires accompanying changes in complementary activities within the ecosystem (Adner and Kapoor, 2010; Hughes, 1983; Rosenberg, 1976; Teece, 2007). The commercialization phase of a new technology would entail coordinated adaptation by focal firms and complementors, who would need to make mutual adjustments in their respective activities during a period of technological and market uncertainty (Teece, 2007; Williamson, 1991a). A focal firm's ability to create value from a new technology would depend on the degree to which it can effectively coordinate accompanying changes among complementors. As compared to market, an alliance organizational form, characterized by cooperation between parties and the existence of communication channels and codes, is more effective in achieving such coordinated adaptation. Hence, firms that have an alliance relationship with their complementors would be better positioned to create value from the new 
technology, and more likely to invest in the new technology than firms that have an arm's-length relationship. ${ }^{3}$

Hypothesis 1: Firms that have an alliance relationship with their complementors will be more likely to invest in a new technology than firms that have an arm 's-length relationship.

An important feature of the integrated organizational form is that it facilitates coordinated adaptation (Williamson, 1991a). This enhanced adaptability might make an integrated firm more likely to invest in a new technology than firms using an arm's-length or an alliance relationship. However, such a prediction would have only considered the benefits while ignoring the costs of integration. This would have been inconsistent with the theories of the firm that explicitly recognize the need to consider both the costs and the benefits of integration. For example, Grossman and Hart (1986) develop a theory of how common ownership shifts the distribution of surplus created by the two complementary parties, creating incentive distortions and resulting in underinvestment. Milgrom and Roberts (1992) develop a theory of how authority in an integrated firm results in parties lobbying to influence decision makers for their own personal benefit. Such influence activities are costly for an integrated firm, as they lower the quality of decision making and divert the attention and effort of parties from more productive activities. Finally, Williamson $(1975,1985)$ describes how internalizing a transaction within a firm creates different types of bureaucratic distortions, such as procurement practices that favor internal units despite a more profitable external alternative, and persistence tendencies that favor continuation of unproductive or obsolete projects.

\footnotetext{
${ }^{3}$ It is certainly plausible that alliance between focal firms and complementors can also help to increase the focal firms' relative bargaining power over downstream buyers. This would increase the value that a firm can capture from the new technology and may be another reason that firms that have an alliance relationship with complementors will be more likely to invest in a new technology than firms that have an arm's-length relationship.
} 
As compared to an integrated form, an alliance form is relatively free from such organizational costs, since focal firms and complementors retain autonomy over their respective tasks. An important differentiating feature of a firm-complementor alliance as compared to a firm-supplier alliance is that the price mechanism of the market that provides for high-powered incentives is likely to be preserved. Compared to a firm-supplier alliance, in which long-term contracts and high customer bargaining power can result in suppliers being governed like organizational units, resulting in incentive attenuation (Makadok and Coff, 2009; Williamson, 1991a), a firm-complementor alliance does not necessarily alter the market-based interaction between alliance partners and their downstream buyers.

In summary, firms that have an alliance relationship with complementors are relatively free from the organizational costs incurred by integrated firms while retaining their ability to achieve coordinated adaptation during the commercialization of a new technology. Hence, as compared to integrated firms, firms that have an alliance relationship with their complementors will be more likely to invest in a new technology. ${ }^{4}$

Hypothesis 2: Firms that have an alliance relationship with their complementors will be more likely to invest in a new technology than firms that integrate into the complementary activities.

\section{$\underline{\text { Alliance Scope as a Shift Parameter }}$}

Research on alliances has suggested that the choice of alliance scope is among the most important choices considered by partnering firms (e.g., Doz and Hamel, 1998; Khanna et al., 1998; Oxley and Sampson, 2004). Alliance scope refers to the extent of activities that partners

\footnotetext{
${ }^{4}$ An integrated mode is likely to be superior to an alliance mode for very high levels of adaptation. Hence, it is possible that for such extreme cases, the benefits of adaptation may supersede the costs of organization and result in integrated firms being better positioned to commercialize new technologies. This requires an important boundary condition for our hypothesis - i.e., the level of adaptation associated with the commercialization of the new technology is of a "moderate" type.
} 
jointly carry out through the alliance as compared to their total set of activities. The broader the scope of activities carried out within the alliance, the greater the extent of common benefits that alliance partners derive from their relationships (Khanna et al., 1998). Greater common benefits help to align the incentives between partnering firms and facilitate cooperation (Agarwal et al., 2010; Dyer and Singh, 1998; Khanna et al., 1998). Broader alliance scope would also make it easier for firms to identify and coordinate changes in the interdependent activities that will interact with the new technology. Hence, the broader the scope of alliance between firms and complementors, the more effective the firms will be in their commercialization of the new technology.

The combination of hypotheses 1 and 2 suggests that we are proposing an inverted Ushaped relationship between the firm-complementor organizational form along the markethierarchy continuum and the firm's propensity to invest in a new technology. We now suggest that the scope of the alliance, by affecting the extent of cooperation and coordination, can act as a shift parameter for the propensity of firms using the alliance mode to invest in a new technology. Hence, the broader the scope of the alliance between firms and their complementors, the greater the likelihood that firms would invest in a new technology.

Hypothesis 3: The broader the scope of the alliance between firms and their complementors, the greater the likelihood that firms will invest in a new technology.

Figure 1 illustrates our theoretical framework linking firm-complementor organizational form to the firm's likelihood of investment in a new technology.

Insert Figure 1 about here 


\section{Organization of Firms and Buyers}

Finally, we consider how firms' governance choices with respect to downstream buyers will affect their likelihood of investment in new technologies. Besides the arm's-length relationship, we consider a plural form of governance in which a firm uses both arm's-length and integrated strategies. This form of governance, often referred to in the strategy literature as tapered integration (Porter, 1980), has been documented for both upstream activities (Harrigan, 1986; Jacobides and Billinger, 2006; Parmigiani, 2007; Rothaermel et al., 2006) and downstream activities (Dutta et al., 1995; Harrigan, 1986; La Fontaine, 1992; Michael, 2000) in the firm's value chain.

While tapered integration with respect to downstream buyers is more costly to set up and more complex to manage than the pure market form, its benefits include reduced information asymmetry that mitigates hold-up hazards, greater bargaining power, and lower demand uncertainty (Dutta et al., 1995; Harrigan, 1986; Michael, 2000; Porter, 1980). Compared to full integration, tapered integration also limits the dulling of incentives and bureaucratic distortions, as firms rely on both internal and external parties for downstream tasks (e.g., Porter, 1980). ${ }^{5}$

Firms pursuing tapered integration strategies will face lower risk during the commercialization of the new technology, as they have preferred access to their downstream buyers. Given that buyers may incur specialized investments to commercialize the new technology, tapered integration also reduces the likelihood of hold-ups. Finally, greater bargaining power would allow firms using tapered integration strategies to appropriate more value from the new technology than firms pursuing market-based strategies. Hence, firms

\footnotetext{
${ }^{5}$ Most of our arguments regarding governance choices of downstream buyers also apply to upstream suppliers. However, we focus on the downstream buyers to maintain consistency with our empirical context.
} 
pursuing tapered integration with respect to downstream buyers will be more likely to invest in a new technology than firms pursuing arm's-length relationships.

Hypothesis 4: Firms that pursue tapered integration strategies downstream in their vertical chains will be more likely to invest in a new technology than firms that pursue arm's-length relationships.

\section{METHODOLOGY}

\section{Industry Background}

The context for our study is the U.S. health care industry. We focus on three critical players that constitute the delivery of health care services - hospitals, physicians, and managed care organizations (MCOs). Our focal firms are hospitals that provide facilities and staff to diagnose and treat patients. Physicians are the primary source of medical expertise for the diagnosis and treatment. The service provided by the physicians is a complement to the service provided by the hospitals, and hence physicians are key complementors to the hospitals (Brandenburger and Nalebuff, 1998: 12). Hospitals' (and physicians') services are packaged and distributed by MCOs downstream as health plans to end-users. Hence, while the hospital-physician relationship corresponds to a firm-complementor relationship, the hospital-MCO relationship corresponds to a firm-distributor relationship. The complementary relationship between hospitals and physicians has also been acknowledged by Gaynor (2006) in his recent review of research on hospitalphysician relationships in the health care literature. He notes that hospitals and physicians depend on each other for creating value and that their respective services are sold downstream to the buyers. The simplified schema of the health care delivery ecosystem is shown in Figure 2. 
Insert Figure 2 about here

\section{Managed Care Organization}

The managed care organization (MCO) is a critical player in the delivery of health care services. MCOs in a given market package and distribute the services offered by hospitals and physicians as health plans. The emergence of MCOs in the early 1980s was in response to significant escalation of health care costs under the traditional fee-for-service system, in which patients were billed for each service provided and the claims were reimbursed from insurers. The insurers themselves did not play any part in the management of the delivery of services such that patients could get a service from any provider and receive a pre-determined reimbursement for that service from the insurer. Because of the fragmented nature of the payment and delivery functions, health care costs rose rapidly (Weisbrod, 1991).

MCOs integrated both the delivery of health care services and the payment functions, and focused on lowering health care costs while maintaining quality. A key feature of the MCO business model was to negotiate low rates with select providers (both hospitals and physicians) and to offer a variety of health plans to meet the needs of different market segments. By stimulating competition among health care providers in order for them to be considered in the network of service providers and by enforcing strict cost controls, especially with respect to new and more expensive services, MCOs slowed the rate of increase in health care costs (Teisberg, Porter, and Brown, 1994). The emergence of MCOs imposed significant pressure on hospitals and physicians to improve their competitive position by lowering their costs and/or improving the quality of their services. In addition, hospitals and physicians took steps to increase their bargaining power over MCOs in order to receive greater reimbursement for their services. These 
considerations led to a wave of mergers, acquisitions, and alliances among service providers (Bazzoli et al., 2004), as well as hospitals acquiring equity interest in some MCOs (Shortell, Morrison, and Hughes, 1989).

\section{Hospital-Physician Governance Forms}

The health care industry provides an ideal context in which to explore the implications of firm-complementor governance modes. The context is characterized by a wide variety of hospital-physician governance forms that include arm's-length relationships, alliances with varying degrees of scope, and fully integrated organizations in which physicians are employed by hospitals (e.g., Burns and Thorpe, 1993; Ciliberto and Dranove, 2006; Cuellar and Gertler, 2006).

On the one end of the governance continuum, an arm's-length relationship between hospitals and physicians entail that while physicians have admitting privileges in hospitals, they remain independent with respect to contracting with MCOs, administrative tasks, and information systems. On the other end of the continuum, an integrated salary model entails that hospitals employ their own physicians.

Besides the arm's-length and integrated modes, four different types of alliance modes are extensively used by hospitals and physicians (AHA, 2009). A key distinguishing factor among these hybrid choices is the scope of the activities that are carried out through the alliance relationship. First, the Independent Practice Association (IPA) alliance entails that hospitals and physicians pursue joint contracting with MCOs while retaining autonomy over administrative tasks and information systems (e.g., Burns et al., 2000; Cuellar and Gertler, 2006). An IPA alliance is relatively easy to organize and incurs minimal set-up costs. Second, the Open 
Physician Hospital Organization (OPHO) alliance is responsible for coordinating administrative tasks between hospitals and physicians as well as negotiating and managing contracts with MCOs. Third, in the Closed Physician Hospital Organization (CPHO) alliance, physicians are exclusively contracted to the hospitals, and the scope of the alliance also extends to coordinating care for the patients (e.g., Cuellar and Gertler, 2006). Finally, the Management Service Organization (MSO) alliance emulates most of the features of the CPHO alliance except that the joint-venture is also responsible for supporting the services of the physicians through staff and equipment. The MSO's services include office support, purchasing and operation of information systems, patient billings and collections, and contract marketing and negotiations (Brown, 1996).

\section{Data}

The primary source of data for the study is the American Hospital Association (AHA), which since 1946 has conducted yearly surveys of all registered hospitals in the United States, with greater than an $80 \%$ response rate (AHA, 2009). Since 1995, AHA has been collecting information on the organizational forms used by hospitals with respect to physicians. In this study, we use AHA annual survey data from 1995 to 2006, supplemented with information on MCOs from the U.S. Department of Health and Human Services and with county-level demographic data from the Census Bureau.

The AHA database included information on 7,525 hospitals from 1995 to 2006. We excluded approximately 8 percent of hospitals that reported multiple governance modes with physicians. Following previous studies of technology adoption in the health care industry (e.g., Baker, 2001; David, Helmchen, and Henderson, 2009), we also excluded psychiatric, children's, and other specialty hospitals that have distinct business models or do not typically need to invest 
in the medical imaging technologies that we examine in this study (XXX). The final sample consisted of 5,367 hospitals. ${ }^{6}$

\section{Measures}

Dependent Variable: We examine the hospital's decision to invest in new medical imaging technologies. These technologies have been key drivers of technological advances in the health care industry (Burns et al., 2000). We focus on two distinct imaging technologies that have emerged at different periods in the industry. Magnetic Resonance Imaging (MRI) is a diagnostic technology that captures high-resolution images of body tissues to detect anomalies such as tumors. While the origins of MRI date back to the early 1970s, its clinical use began around 1982. Positron Emission Tomography (PET) is among the most recent diagnostic technologies, commercialized in the early 1990s. PET provides a cross-sectional image based on metabolic activity of cells, which enables functional level analysis of body tissues. Each of these imaging technologies constitutes a significant investment for a hospital (Baker, 2001; Teplensky et al., 1995). A typical investment in these technologies includes capital expenditure in excess of $\$ 2$ million to purchase the equipment and additional maintenance and personnel costs. As with most strategic investments, hospitals face the dilemma of whether and when to invest in these imaging technologies. An earlier investment may allow a hospital to position itself as a technology leader (Luft et al., 1986) and gain market share over its rivals (e.g., Ho, 2009). However, earlier investments are also made under considerable risk regarding the capability and the implementation of the new technology, the extent of market demand, and the level of reimbursements that the hospital will receive from MCOs (Teplensky et al., 1995).

\footnotetext{
${ }^{6} \mathrm{We}$ also performed additional analysis that included data from all 7,525 hospitals and our results were consistent with the ones reported in the paper.
} 
Figure 3 shows the trend in the percentage of hospitals that have invested in MRI and PET technologies from 1995 to 2006. Our dependent variable measures whether a hospital has invested in the new imaging technology in a given year. A hospital is assumed to have invested in the new technology during the first year that it reports the technology's availability in the AHA annual survey.

Insert Figure 3 about here

In some instances, there was inconsistency in the reported data. A hospital might report the technology as available one year but not the next. In other cases, a hospital reported the availability of the technology in one year but the data were missing the following year and resumed in later years. We tested for the robustness of our findings by following the procedure used by Baker (2001). Specifically, in the case of inconsistent data, we used as the year of new technology investment the earliest of the first two consecutive years in which the hospital reported the availability of the focal technology. For example, when a hospital reported the availability of the technology in 1995, 1997, and 1998 but not in 1996, we consider the year of investment to be 1997. In the case of missing data, we chose the year of new technology investment as the earliest of the first three successive years in which the hospital reported the availability of the focal technology. For example, when a hospital reported the availability in 1995, 1997 and 1998 but the data were missing in 1996, we consider the investment year to be 1995. The results from these robustness tests were fully consistent with our reported results.

Independent Variables: We measured hospital-physician governance form with dummy variables that were coded based on the categories used in the AHA survey. Our base category of 
governance mode is an arm's-length relationship between hospitals and physicians in which physicians have admitting privileges in hospitals but remain independent with respect to MCO contracting, administrative tasks, and information systems. We used a dummy variable to code whether the hospital formed an alliance with physicians. The variable, Complementor Alliance, took a value of 1 if the hospital used any of the four different types of alliance with physicians Independent Practice Association (IPA), Open Physician Hospital Organization (OPHO), Closed Physician Hospital Organization (CPHO) and Management Service Organization (MSO), and 0 otherwise. The dummy variable, Complementor Integration, took the value of 1 if the hospital reported using an Integrated Salary Model (ISM).

In order to test the effect of alliance scope, we created separate categories of low, medium, and high alliance scope. Our categorization is based on the rank ordering of the extent of activities that hospitals and physicians carry out through the alliance as compared to their total set of activities (e.g., Khanna et al., 1998). An IPA alliance is characterized by hospitals and physicians collaborating on contracting with MCOs while retaining autonomy over administrative tasks, information systems, and patient care (e.g., Burns et al., 2000; Cuellar and Gertler, 2006). It was categorized as low alliance scope. An OPHO alliance between hospitals and physicians not only pursued joint contracting with MCOs but also shared administrative services. It was categorized as medium alliance scope. Finally, a hospital that used either a $\mathrm{CPHO}$ or MSO alliance was categorized as having high alliance scope. In this case, physicians are exclusively contracted to the hospital, and the activities underlying the alliance include joint contracting with MCOs, sharing of administrative services, and coordinating patient care. While $\mathrm{CPHO}$ and MSO alliance forms are very similar in their scope, as a test of robustness, we 
estimated a model that included their separate effects. The coefficients and the significance levels were almost identical to the aggregated category.

A hospital typically works with a number of MCOs that distribute its services. Many of these interactions are governed through arm's-length relationships. However, several hospitals reported as having an equity interest in at least one of the MCOs. ${ }^{7}$ For example, Sanpete Valley Hospital (Mount Pleasant, Utah) has an equity interest in Intermountain Healthcare MCO that distributes its services in addition to other independent MCOs such as Altius Healthplans and Healthy U. We used a dummy variable, Buyer Tapered Integration, to identify such hospitals.

Control Variables: We controlled for a number of hospital-level and market-level covariates that may affect a hospital's propensity to invest in a new technology. Consistent with the healthcare literature, Hospital Size is measured as the total number of beds. We used dummy variables to characterize the hospital as a Medical School Member, Teaching School Member, Not-for-Profit, or Government Owned. The hospital's Capacity Utilization is measured as the ratio of annual inpatient days and the total annual capacity of the hospital, obtained by multiplying the total number of hospital beds times 365 (Banker, Conrad, and Strauss, 1986). The hospital's Outpatient Ratio is measured as the ratio of total number of annual outpatient visits and the total annual number of inpatient admissions (Ciliberto, 2006). The market-level controls include the Number of General Hospitals in the county where the hospital is located and Market Concentration, measured as the Herfindahl index of hospital market shares in the county. We controlled for the county's demographic characteristics through Unemployment Rate and Per Capita Income.

\footnotetext{
${ }^{7}$ The question in the AHA survey specifically asked for an equity interest in MCO organizations that are associated with health maintenance organizations and preferred provider organizations, the two most common forms of managed care.
} 
Many recent studies in the health care literature have reported that the emergence of MCOs in the 1980s has imposed excessive economic constraints on hospitals through lower reimbursement rates and strict cost controls. As a result, these studies found that greater market penetration of MCOs over traditional insurance organizations have lowered the propensity of hospitals to invest in new technologies (e.g., Baker, 2001; Douglas and Ryman, 2003; Mas and Seinfeld, 2008). The literature has used different data sources to measure the penetration of MCOs in a given geographical market. For example, some studies have used HMO penetration rate (e.g. Baker, 1997) whereas others have used Medicare penetration rate (e.g. Dranove, Simon, and White, 1998). There are advantages and disadvantages with each of these data sources (Dranove et al., 1998). In this study, we used Medicare managed care penetration rate data (Baker, 1997) from the Area Resource File provided by the U.S. Department of Health and Human Services as a measure of managed care penetration. We control for this effect through the variable MCO Penetration, which takes a value of 1 if the percentage of Medicare enrollees in the county exceed $15 \%$ and 0 otherwise (e.g. Baker, 2001). We tested for the robustness of our findings by using the alternative HMO penetration level information for the year 1998 obtained from the Area Resource File. While the standard error for the MCO penetration estimate was larger, the magnitude and significance levels of our hypothesized covariates remain almost unchanged.

Finally, we include state fixed effects to control for unobserved differences in health care regulation (e.g., certificate of need) across the different states (Hillman and Schwartz, 1985). Table 1 provides a brief summary of the variables used in the analysis.

Insert Table 1 about here 


\section{Analysis}

Many hospitals in our sample did not invest in the medical imaging technologies during the period of observation. Hence, our data is right-censored. Consistent with prior studies examining the firm's timing of strategic investments in new technologies (e.g., Baker, 2001; Mitchell, 1989), we used hazard rate models to test our predictions. Specifically, we used the Cox semiparametric proportional hazards model, which allows for a fully flexible, nonparametric baseline hazard, and hence does not require making additional assumptions about the shape of the baseline hazard over time (Cox, 1975).

In addition, a number of hospitals in our sample had invested in the MRI technologies prior to the first available observation in our dataset, and hence these observations were leftcensored. We follow the standard approach in the literature to exclude the observations that were left-censored (Allison, 1982). To ensure that our results are not biased by the exclusion of these observations, we separately estimated the effects of our covariates on the left-censored observations using the probit model. The results from the probit model, reported in the robustness tests section, are nearly identical to the results obtained from the Cox models.

\section{RESULTS}

Table 2 shows the summary statistics and correlations between our covariates. Table 3 reports the results from the Cox models for the two different medical imaging technologies. Models 1 and 4 are our baseline models for the hospitals' adoption of PET and MRI technologies, respectively. Models 2 and 3 allow us to test our predictions using data from hospitals' adoption of PET technology, and Models 5 and 6 allow us to test our predictions using data from hospitals' adoption of MRI technology. 
Insert Table 2 about here

The results from the baseline models are consistent with our expectations and prior research in the health care industry (e.g., Baker and Phibbs, 2002; Hillman and Schwartz, 1985; Robinson, 1996; Teplensky et al., 1995). On the one hand, hospitals that are large, are not-forprofit, are members of a medical school association, and have greater capacity utilization are more likely to invest in the new medical imaging technologies. On the other hand, hospitals that have a greater outpatient ratio and are located in more concentrated markets are less likely to invest in the new technologies. The estimates for MCO penetration are negative and significant for both PET and MRI technologies. Hence, our results provide continued support of prior findings that the emergence of MCOs is negatively correlated with hospitals' investments in new technologies (Baker and Phibbs, 2002; Baker, 2001; Mas and Seinfeld, 2008). The coefficient for the number of hospitals is negative but insignificant.

While we expected hospitals that are members of a teaching school association to be more likely to invest in the new technology, we found this effect to be positive and significant only for the PET technology. The significant and negative effect for MRI technology could be due to the fact that many of these hospitals that had invested in the MRI technology were leftcensored and hence excluded from the sample. This was confirmed in our estimates from the probit model using the left-censored data. Finally, the coefficient for Not-for-Profit was negative and significant for MRI technology only. ${ }^{8}$

Insert Table 3 about here

\footnotetext{
${ }^{8}$ We note that studies in the health care industry have generally found mixed results with respect to differences in
} technology investments between for-profit and not-for-profit hospitals (e.g., Mas and Seinfeld, 2008). 
In Hypothesis 1, we predicted that firms that have an alliance relationship with their complementors will be more likely to invest in a new technology than firms that have an arm'slength relationship. This prediction was supported for both technologies (Models 2 and 5). Note that our baseline category is the arm's-length relationship between the hospitals and the physicians. The coefficients for complementor alliance are significant and positive for both PET and MRI technologies. In considering the magnitude of estimated coefficients, we see that hospitals that have an alliance relationship with physicians are $32 \%(33 \%)$ more likely to invest in the PET (MRI technology) than hospitals that have an arm's-length relationship with physicians.

In Hypothesis 2, we predicted that firms that have an alliance relationship with their complementors will be more likely to invest in a new technology than firms that integrate into the complementary activities. The coefficient for complementor integration is insignificant for both PET and MRI technologies. A comparison of the coefficients for complementor alliance with that for complementor integration using the Wald test (Table 4) reveals support for Hypothesis 2.

In Hypothesis 3, we predicted that a firm's propensity to invest in the new technology is increasing in the scope of the firm-complementor alliance. Consistent with our hypothesis, the coefficient of alliance scope in Table 4 is increasing in the scope of the alliance. With the exception of low alliance scope for the PET technology, all of the alliance scope coefficients are positive and significant. Hospitals with low alliance scope are $21 \%$ more likely to invest in the MRI technology than hospitals that have an arm's-length relationship with physicians. Hospitals with medium alliance scope are 26\% (27\%) more likely to invest in the PET (MRI) technology 
than hospitals that have an arm's-length relationship with physicians. Finally, hospitals with high alliance scope are 45\% (65\%) more likely to invest in the PET (MRI) technology than hospitals that have an arm's-length relationship with physicians. A comparison of the coefficients for the low and high alliance scope using the Wald test supports Hypothesis 3 for both technologies. However, the difference between the coefficients for the medium and high alliance scope was significant only for MRI technology, and the difference between the coefficients for the low and medium alliance scope was insignificant for both PET and MRI technologies.

Insert Table 4 about here

Finally, in Hypothesis 4, we predicted that firms pursuing tapered integration strategies downstream in their vertical chains are more likely to invest in new technology than firms pursuing market-based strategies. This prediction was supported for both technologies. The coefficient for buyer tapered integration is significant and positive for both PET and MRI technologies. Hospitals that use tapered integration strategies with MCOs are $15 \%(25 \%)$ more likely to invest in PET (MRI) technology than hospitals that use only arm's-length relationships.

\section{Robustness Tests}

An important issue to consider with our analysis is the possibility of hospitals self selecting into the different governance modes that could potentially bias our estimates. In order to test the robustness of our results to this potential endogeneity bias, we used a matching estimator approach. Matching estimators have been widely used in economics and have recently been used by scholars in management to address selection bias in empirical specifications (e.g., 
Gonzalez and Pazo, 2008; Rawley and Simcoe, 2009; Sampson, 2005; Zhao, 2009). This nonparametric approach compares the statistical results obtained in a treatment group with those obtained in a comparable control group. The main purpose of the matching estimator is to try to reestablish the conditions of a natural experiment so that the comparison between the two groups allows for a causal inference (Abadie, Drukker et al., 2004). We use matching estimators to evaluate the effect of hospital-physician and hospital-MCO governance modes on the hospital's propensity to invest in new imaging technologies. Our control group is drawn from the hospitals that maintained the same organizational form throughout the period of study. Our treatment group is drawn from the hospitals that shifted their organizational form.

We briefly illustrate the specification that we use to estimate our results. Let $i$ index the hospital in our sample, and let $T$ be a dummy variable that takes the value of 1 if hospital shifts its governance mode and 0 otherwise. Let $Y_{\mathrm{i}}(T)$ represent the hospital's decision to invest in the new technology. So $Y_{i}(0)$ represents the hospital's decision to invest if it had maintained its governance mode, and $Y_{i}(1)$ represents the same hospital's decision to invest if it had shifted its governance mode. Clearly, if both results were simultaneously observed, the effect of the hospital-physician and hospital-MCO governance choice for hospital $i, Y i(1)-Y i(0)$, would be directly observable. The population average of this effect could be obtained as $E[Y(1)-Y(0)]$, and its sample counterpart as $(1 / N) \sum_{i=1}^{N}[Y i(1)-Y i(0)]$, where $N$ is the number of hospitals. However, $Y i(1)$ and $Y i(0)$ are not simultaneously observable. For example, in our study, we cannot observe the same hospital to shift from alliance to integration and maintain the alliance mode as well. In other words, the two events - shifting and maintaining the governance mode are mutually exclusive. 
The matching estimators provide an alternative approach. Let $j$ (while $i \neq j$ ) index the hospitals in our sample, and assume that hospitals $i$ and $j$ closely match each other based on the observables. By observing $Y_{i}(0)$ and $Y_{j}(1)$, we can use $Y_{j}(1)$ as a counterfactual value of $Y_{i}(1)$. We use the bias-corrected nearest-neighbor matching estimator proposed by Abadie and Imbens (2006) to find the counterfactual value. ${ }^{9}$ For each hospital $i$, the standard nearest-neighbor matching estimator searches for the most similar hospital with the opposite treatment. We match hospitals based on hospital attributes, MCO penetration, market competition, and demand. Figures 4, 5, and 6 plot the kernel densities of the propensity scores for the unmatched and matched treatment and control groups. The effectiveness of our matching procedure is evident from greater similarity in kernel densities among the matched groups as compared to the unmatched groups.

Insert Figures 4, 5, and 6 about here

Our main results are supported if we find that the difference in the likelihood of investment between the treatment and the control groups is significant in our predicted direction. For example, with respect to Hypothesis 1, our control group comprises hospitals that use an alliance mode, and the matched treatment group comprises hospitals that shift from an alliance to an arm's-length relationship with physicians. Hypothesis 1 is supported if we find that the hospitals in the treatment group are less likely to invest in the new imaging technology than similar hospitals in the control group. The results, reported in Table 5, are fully supportive of Hypotheses 1, 2, and 4. While we would have preferred to test the robustness of all hypotheses,

\footnotetext{
${ }^{9}$ This was implemented in STATA 10.0 using the NNMATCH procedure provided by Abadie, Herr, et al. (2004).
} 
we are limited by our data. Only a small number of hospitals have changed the scope of the alliance during the period of study, and hence we are unable to create robust control and treatment groups to test Hypothesis 3.

Insert Table 5 about here

Another potential concern with our analysis is that in estimating the hospital's likelihood of investment in MRI technology, we excluded a large number of hospitals who had adopted the technology prior to our window of observation. It is possible that the exclusion of these leftcensored observations may have created a selection bias in our sample. To ensure that our results for the MRI technology are not biased by the exclusion of these hospitals, we performed a crosssectional analysis using a probit model for the year 1995, the first year of observation in the study. The estimated results from the probit model, reported in Table 6, are nearly identical to the results from the Cox models and provide additional support for our predictions.

Insert Table 6 about here

\section{DISCUSSION}

The organization of activities within and outside firm boundaries has long been of interest to scholars in economics and strategic management. Scholars have shed light on a variety of organizational forms that firms use to manage interdependent activities, being explicit about the tradeoffs associated with the different governance modes (e.g., Dyer and Singh, 1998; Harrigan, 1986; Hennart, 1993; Mahoney, 1992; Williamson, 1991a). This study contributes to that literature by examining the relationship between firms' governance choices and an important type of strategic behavior - i.e., investments in new technologies. We expand the analysis of 
organizational forms from the literature's focus on the upstream and downstream activities in the firm's vertical chain to also consider complements that are a vital part of the firm's business ecosystem (Brandenburger and Nalebuff, 1998; Teece, 2007). Our central premise is that by facilitating the coordination of changes that underlie the commercialization of new technology and by enhancing the firm's strategic position with respect to other players in its ecosystem, a firm's organizational form plays an important role in creating and capturing value from investments in new technology.

We test our arguments in the context of the U.S. health care industry from 1995 to 2006. We explore how hospitals' investments in new imaging technologies are shaped by their mode of governance with physicians — - key complementors to hospitals—and with MCOs—primary distributors of hospital and physician services. We find that hospitals that pursue alliances with physicians are more likely to invest in new imaging technologies than hospitals that either have an arm's-length relationship with physicians or are integrated and employ their own physicians. We also find that among hospitals pursuing alliances with physicians, the likelihood of investments in new imaging technologies is increasing in the scope of the alliance. Finally, we find that hospitals that pursue tapered integration strategies with MCOs such that they use both hierarchy- and market-based governance modes are more likely to invest in new imaging technologies than hospitals that use only market-based governance.

The study contributes to some important issues in the strategy literature. While a vast body of empirical literature has explored the determinants and performance implications of firm boundaries and governance modes, the literature has been surprisingly silent on how such governance choices affect strategic behavior, an important precursor to firm performance within its competitive environment. We hope that our results would encourage scholars to integrate their 
examination of coordination among interdependent activities with that of competition among rivals and other players in the ecosystem so as to improve our understanding of firm strategies and competitive advantage.

We believe that ours is the first study in the strategy literature that has explicitly considered complements in examining different types of organizational forms and their strategic implications for focal firms. In contrast to the predominant supply-side efficiency considerations that are made with respect to firms' governance modes, the analysis of complements allows for the inclusion of demand side benefits that firms may enjoy by coordinating complementary activities and enhancing the value of their focal products or services.

An interesting result of the study was the inverted U-shaped relationship that we observed with respect to the hospital-physician governance choices along the market-hierarchy continuum and the likelihood of technology investment. Hospitals pursuing alliances with physicians were more likely to invest in new imaging technologies than hospitals pursuing either arm's-length or integrated modes. While scholars have emphasized the tradeoffs that exist between market- and hierarchy-based organizational forms (Dyer, Kale, and Singh, 2004; Gibbons, 2005; Williamson, 1991a), our results support the conjecture that the hybrid alliance form may provide a more balanced mode of organization that allows for coordination while preserving incentives. This result also supports call for empirical research on firm boundaries to consider a broader set of governance modes (e.g., Villalonga and McGahan, 2005) in order to better understand the tradeoffs associated with each of the organizational forms.

The literature on strategic alliances has provided useful dimensions to help characterize the different types of alliances. Among them, the scope of the alliance between alliance partners has been widely recognized to be an important "design" choice (e.g., Doz and Hamel, 1998; 
Khanna et al., 1998). Our results reinforce the need to consider the variance in alliance scope rather than the existence of the alliance per se. Moreover, alliances between complementors are becoming increasingly prevalent and we hope that our study would encourage scholars examining firms' alliance portfolios to explicitly consider alliance between complementors as part of the firms' alliance strategies.

Finally, our findings contribute to the understanding of technology adoption in the context of business ecosystems. We add to the factors considered by the adoption literature (e.g., Geroski, 2000; Griliches, 1957; Rogers, 1995) by suggesting that the distribution of organizational forms in a given industry would play an important role in explaining the pattern of new technology adoption. For example, the relative distribution of hospitals that have an alliance relationship with physicians would affect the pace with which hospitals adopt new imaging technologies. Scholars examining patterns of technology adoption could benefit from an explicit consideration of heterogeneity in organizational forms in explaining the rate of technology adoption. The consistency in the results among the two technologies in which we examined the adoption patterns of different types of adopters (Rogers, 1995) - innovators and early adopters in the case of PET technology and majority adopters in the case of MRI technology, provide further evidence that our theorized mechanisms are likely to be independent of some of the dominant explanations in the adoption literature.

While we have taken care in this examination, the study of course has a number of limitations. It is conducted in the context of a single industry and we are unable to establish the generalizability of our findings across different settings. It will be of interest to see whether our results can be replicated in other contexts and what boundary conditions may be needed to extend the generalizability of our findings. Our focus on medical imaging technologies, while 
allowing for an examination of a significant technology investment by hospitals, precludes us from making generic assertions on all forms of technology investments. For example, our predictions are based on a key premise that the successful commercialization of technologies requires coordinated changes between focal firms and complementors. It is possible that certain technological investments may not have a direct bearing on complementary activities and therefore, will be outside the scope of our predictions. Another important caveat of this study is that we are not implying a correspondence between a firm's technology investment and its performance outcome. We are merely suggesting a correspondence between a firm's organizational form and its propensity to invest in new technologies. Hence, we make no claims that in our context, alliances are a superior form of governance. Finally, while we have attempted to address the endogeneity bias that may exist due to hospital's self-selection into the different governance modes through additional robustness tests, we cannot fully address this possibility.

In conclusion, the study situates a firm in the context of its business ecosystem encompassing interdependent activities and value chains. It explores how organizational choices - arm's-length contracting, alliance or ownership, with respect to complementary activities and downstream distribution affect the firms' investments into new technologies. We contribute to the literature on firm boundaries by considering how boundary choices and governance modes shape firm behavior within the competitive environment. We also move beyond the literature's focus on upstream inputs and downstream distribution to also consider complements that form an important part of the firm's business environment. We hope that our results would encourage scholars to extend research on firm boundary and governance choices to explore the link between 
coordination mechanisms and competitive behavior, and to consider such choices in the context of the business ecosystems.

\section{REFERENCES}

Abadie A, Drukker D, Herr JL, Imbens GW. 2004. Implementing matching estimators for average treatment effects in Stata. Stata Journal 4: 290-311.

Abadie A, Herr JL, Imbens GW, Drukker DM. 2004. NNMATCH: Stata module to compute nearestneighbor bias-corrected estimators. Unpublished.

Abadie A, Imbens GW. 2006. Large sample properties of matching estimators for average treatment effects. Econometrica 74 (1): 235-267.

Adner R, Kapoor R. 2010. Value creation in innovation ecosystems: how the structure of technological interdependence affects firm performance in new technology generations. Strategic Management Journal 31 (3): 306-333.

Agarwal R, Croson R, Mahoney J. 2010. The role of incentives and communication in strategic alliances: an experimental investigation. Strategic Management Journal 31 (4): 413-437.

Aggarwal V, Siggelkow N, Singh H. 2010. Governing collaborative activity: interdependence and the impact of coordination and exploration. Strategic Management Journal, forthcoming.

AHA (American Hospital Association). 2009. AHA data: insights. Resources. Online document at: www.ahadata.com.

Allison PD. 1982. Discrete-time methods for the analysis of event histories. In Sociological Methodology, Leinhardt S (ed). Jossey-Bass: San Francisco, CA: 61-98.

Argyres NS. 1995. Technology strategy, governance structure and interdivisional coordination. Journal of Economic Behavior and Organization 28: 337-358.

Armour HO, Teece DJ. 1980. Vertical integration and technological innovation. The Review of Economics and Statistics 62 (3): 470-474.

Baker L, Phibbs C. 2002. Managed care, technology adoption, and health care: the adoption of neonatal intensive care. RAND Journal of Economics 33 (3): 524-548.

Baker LC. 1997. The effect of HMOs on fee-for-service health care expenditures: evidence from Medicare. Journal of Health Economics 16: 453-481.

Baker LC. 2001. Managed care and technology adoption in health care: evidence from magnetic resonance imaging. Journal of Health Economics 20: 395-421.

Banker RD, Conrad RF, Strauss RP. A comparative application of data envelopment analysis and translog methods: an illustrative study of hospital production. Management Science 32 (1): 30-44.

Barnard C. 1938. The functions of the executive. Cambridge, MA: Harvard University Press.

Bazzoli GJ, Dynan L, Burns LR, Yap C. 2004. Two decades of organizational change in health care: what have we learned? Medical Care Research and Review 61 (3): 247-331.

Borys B, Jemison D. 1989. Hybrid organizations as strategic alliances: theoretical issues in organizational combinations. Academy of Management Review 14 (1): 234-249. 
Brandenburger AM, Nalebuff BJ. 1998. Co-Opetition: A Revolution Mindset That Combines Competition and Cooperation. Currency: New York.

Brown M. 1996. Integrated Health Care Delivery: Theory, Practice, Evaluation, and Prognosis. Jones \& Bartlett Publishers: Sudbury, MA.

Burns LR, Cisneros E, Ferniany W, Singh H. 2010. Strategic alliances between buyers and suppliers: lessons from the medical imaging industry. In Handbook of Strategic Management of Supply, edited by C. Harland, R. Lamming, and E. Schneller. Thousand Oaks, Calif.: Sage.

Burns LR, Thorpe DP. 1993. Trends and models in physician-hospital organization. Health Care Management Review 18 (4): 7-20.

Ciliberto F. 2006. Does organizational form affect investment decisions? Journal of Industrial Economics 54 (1): 63-93.

Ciliberto F, Dranove D. 2006. The effect of physician-hospital affiliations on hospital prices in California. Journal of Health Economics 25 (1): 29-38.

Cox DR. 1975. Partial likelihood. Biometrika 62: 269-276.

Cuellar A, Gertler P. 2006. Strategic integration of hospitals and physicians. Journal of Health Economics 25: $1-28$.

David G, Helmchen L, Henderson R. 2009. Does advanced medical technology encourage hospitalist use and their direct employment by hospitals? Health Economics 18: 237-247.

Douglas TJ, Ryman JA. 2003. Understanding competitive advantage in the general hospital industry: evaluating strategic competencies. Strategic Management Journal 24 (4): 333-347.

Doz Y. 1996. The evolution of cooperation in strategic alliances: initial conditions or learning processes. Strategic Management Journal 17: 55-84.

Doz Y, Hamel G. 1998. Alliance Advantage: The Art of Creating Value through Partnering. Harvard Business School Press: Boston, MA.

Dranove D, Simon CJ, White WD. 1998. Determinants of managed care penetration. Journal of Health Economics 17: 729-745.

Dutta S, Bergen M, Heide JB, John G. 1995. Understanding dual distribution: the case of reps and house accounts. Journal of Law, Economics, \& Organization 11 (1): 189-204.

Dyer JH. 1996. Specialized supplier networks as a source of competitive advantage: evidence from the auto industry. Strategic Management Journal 7(4): 271-291.

Dyer JH, Nobeoka K. 2000. Creating and managing a high performance knowledge-sharing network: the Toyota case. Strategic Management Journal 21: 345-367.

Dyer JH, Kale P, Singh H. 2004. When to ally and when to acquire. Harvard Business Review 82 (7-8): $108-115$.

Dyer JH, Singh H. 1998. The relational view: cooperative strategy and sources of interorganizational competitive advantage. Academy of Management Review 23 (4): 660-679.

Gawer A, Henderson R. 2007. Platform owner entry and innovation in complementary markets: evidence from Intel. Journal of Economics and Management Strategy 16: 1-34.

Gaynor M. 2006. Is vertical integration anticompetitive? Definitely maybe (But that's not final). Journal of Health Economics 25: 175-180.

Geroski, P. A., 2000. Models of technology diffusion. Research Policy 29 (4-5): 603-625. 
Gibbons R. 2005. Four formal(izable) theories of the firm? Journal of Economic Behavior \& Organization 58: 200-245.

Gonzalez X, Pazo C. 2008. Do public subsidies stimulate private R\&D spending? Research Policy 37 (3): 371-389.

Griliches, Z. 1957. Hybrid corn: an exploration in the economics of technological thange. Econometrica 25 (4): 501-522.

Grossman S, Hart O. 1986. The costs and benefits of ownership: a theory of vertical and lateral integration. Journal of Political Economy 94 (4): 691-719.

Gulati R, Lawrence PR, Puranam P. 2005. Adaptation in vertical relationships: beyond incentive conflict. Strategic Management Journal 26 (5): 415-440.

Gulati R, Singh H. 1998. The architecture of cooperation: managing coordination costs and appropriation concerns in strategic alliances. Administrative Science Quarterly 43: 781-814.

Harrigan KR. 1984. Formulating vertical integration strategies. Academy of Management Review 9 (4): 638-652.

Harrigan KR. 1986. Matching vertical integration strategies to competitive conditions. Strategic Management Journal 7 (6): 535-555.

Hart O, Moore J. 1990. Property rights and the nature of the firm. Journal of Political Economy 98: 1119-1158.

Hennart, JF. 1993. Explaining the swollen middle: why most transactions are a mix of market and hierarchy. Organizational Science 4: 529-547.

Hillman A, Schwartz JS. 1985. The adoption and diffusion of CT and MRI in the United States: a comparative analysis. Medical Care 23 (11): 1283-1294.

Ho K. 2009. Insurer-provider networks in medical care market. American Economic Review 99 (1): 393430.

Hughes TP. 1983. Networks of Power: Electrification in Western Society 1880 - 1930. Baltimore: Johns Hopkins University Press.

Iansiti M, Levien R. 2004. The Keystone Advantage: What the New Dynamics of Business Ecosystems Mean for Strategy, Innovation and Sustainability. Harvard Business School Press: Boston, MA.

Jacobides MG, Billinger S. 2006. Designing the boundaries of the firm: from "make, buy or ally" to the dynamic benefits of vertical architecture. Organization Science 17 (2): 249-261.

Khanna T, Gulati R, Nohria N. 1998. The dynamics of learning alliances: competition, cooperation and relative scope. Strategic Management Journal 19 (3): 193-210.

Kogut B. 1988. Joint ventures: theoretical and empirical perspectives. Strategic Management Journal 9 (4): 319-332.

Lafontaine F. 1992. Agency theory and franchising: some empirical results. RAND Journal of Economics 23 (2): 263-283.

Lieberman MB, and Montgomery DB. 1988. First-mover advantages. Strategic Management Journal 9: $\underline{41-58 .}$

Luft HS, Robinson JC, Garnick DW, Maerki SC, McPhee SJ. 1986. The role of specialized clinical services in competition among hospitals. Inquiry 23 (1): 83-94. 
Mahoney JT. 1992. The choice of organizational form: vertical financial ownership versus other methods of vertical integration. Strategic Management Journal 13 (9): 559-584.

Makadok R, Coff RW. 2009. Both market and hierarchy: an incentive-system theory of hybrid governance forms. Academy of Management Review 34 (2): 297-319.

Mas N, Seinfeld J. 2008. Is managed care restraining the adoption of technology by hospitals? Journal of Health Economics 27: 1026-1045.

Ménard C. 2004. The economics of hybrid organizations. Journal of Institutional and Theoretical Economics 160 (3): 345-376.

Michael SC. 2000. Investments to create bargaining power: the case of franchising. Strategic Management Journal 21(4): 497-514.

Milgrom, P., Roberts, J. 1992. Economics, Organization and Management. Prentice-Hall: Englewood Cliffs, NJ.

Mitchell W. 1989. Whether and when? Probability and timing of incumbents' entry into emerging industrial subfields. Administrative Science Quarterly 34: 208-234.

Mitchell W, Singh K. 1992. Incumbents' use of pre-entry alliances before expansion into new technical subfields of an industry. Journal of Economic Behavior and Organization 18: 347-372.

Moore JF. 1993. Predators and prey: a new ecology of competition. Harvard Business Review 71 (3): 75-86.

Moore JF. 1996. The Death of Competition: Leadership and Strategy in the Age of Business Ecosystems: Harper Business: New York.

Mullainathan S, Scharfstein S. 2001. Do firm boundaries matter? American Economic Review 91 (2): 195-199.

Oxley J, Sampson R. 2004. The scope and governance of international R\&D alliances. Strategic Management Journal, Special Issue 25(8-9): 723-749.

Ozcan P, Eisenhardt KM. 2009. Origin of alliance portfolio: entrepreneurs, network strategies, and firm performance. Academy of Management Journal 52 (2): 246-279.

Parmigiani A. 2007. Why do firms both make and buy? An investigation of concurrent sourcing. Strategic Management Journal 28(3): 285-311.

Pierce L. 2009. Big losses in ecosystem niches: how core firm decisions drive complementary product shakeout. Strategic Management Journal 30 (3): 323-347.

Porter M. 1980. Competitive Strategy: Techniques for Analyzing Industries and Competitors. Free Press: New York.

Porter M. 1998. Competitive Advantage: Creating and Sustaining Superior Performance (new edition). Free Press: New York.

Rawley E, Simcoe T. 2009. Diversification and diseconomies of scope, and vertical contracting. Management Science, forthcoming.

Robinson JC. 1996. Decline in hospital utilization and cost inflation under managed care in California. Journal of the American Medical Association 276 (13): 1060-1064.

Rogers EM. 1995. Diffusion of Innovations. Free Press: New York. 
Rothaermel FT, Hitt MA, Jobe LA. 2006. Balancing vertical integration and strategic outsourcing: effects on product portfolio, product success, and firm performance. Strategic Management Journal 27(11): 1033-1056.

Rosenberg, N. 1976. On Technological Expectations. The Economic Journal 86 (343): 523-535.

Sampson RC. 2005. Experience effects and collaborative returns in R\&D alliances. Strategic Management Journal 26 (11): 1009-1031.

Shortell SM, Morrison EM, Hughes SL. 1989. The keys to successful diversification: lessons from leading hospital systems. Hospital Health Service Administration 34 (4): 471-492.

Teece DJ. 2007. Explicating dynamic capabilities: the nature and microfoundations of (sustainable) enterprise performance. Strategic Management Journal 28 (13): 1319-1350.

Teisberg E, Porter M, Brown G. 1994. Making competition in health care work. Harvard Business Review 72 (4): 131-141.

Teplensky JD, Pauly MV, Kimberly JR, Hillman AL, Schwartz JS. 1995. Hospital adoption of medical technology: an empirical test of alternative models. Health Services Research 30 (3): 437-465.

Villalonga B, McGahan AM. 2005. The choice among acquisitions, alliances, and divestitures. Strategic Management Journal 26 (13): 1183-1208.

Weisbrod B. 1991. The health care quadrilemma: an essay on technological change, insurance, quality of care, and cost containment. Journal of Economic Literature 29: 523-552.

Williamson OE. 1975. Markets and Hierarchies: An Analysis and Antitrust Implications. Free Press: New York.

Williamson OE. 1985. The Economic Institutions of Capitalism: Firms, Markets, Relational Contracting. Free Press, Collier Macmillan: New York, London.

Williamson OE. 1991a. Comparative economic organization: the analysis of discrete structural alternatives. Administrative Science Quarterly 36: 269-296.

Williamson OE. 1991b. The logic of economic organization.In The Nature of The Firm, Williamson OE, Winter S (eds). Oxford University Press: Oxford; 90-117.

Zhao X. 2009. Technological innovation and acquisitions. Management Science 55(7): 1170-1183.

Zollo M, Reuer JJ, Singh H. 2002. Interorganizational routines and performance in strategic alliances. Organization Science 13: 701-713. 


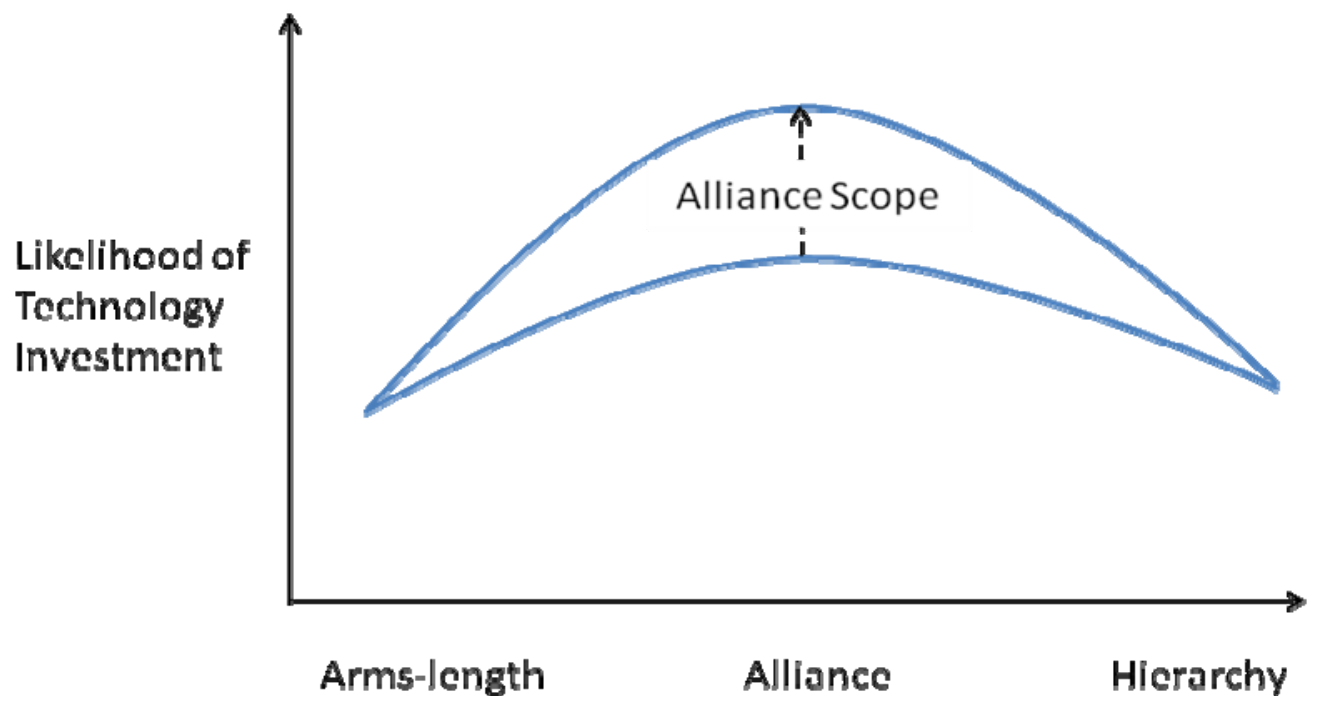

Figure 1: An integrative framework linking firm-complementor organizational form and the firm's likelihood of investment in a new technology

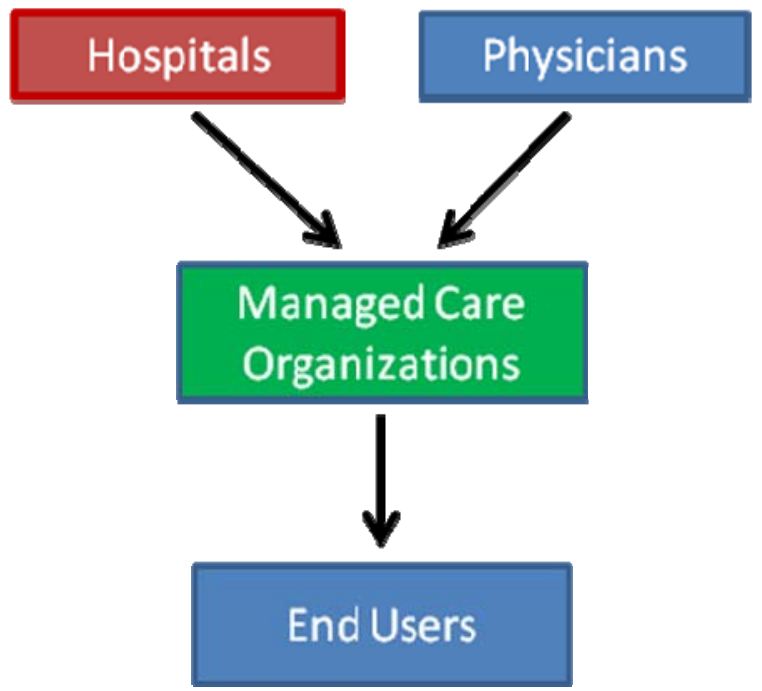

Figure 2: Simplified schema of the health care delivery ecosystem ${ }^{\mathrm{a}}$

${ }^{a}$ Lines indicate service contracts and arrows indicate the flow of services in return for payments (patient copayments, though present from end-users to physicians and hospitals, are not considered here, as they are a significantly small proportion of the total payment. 


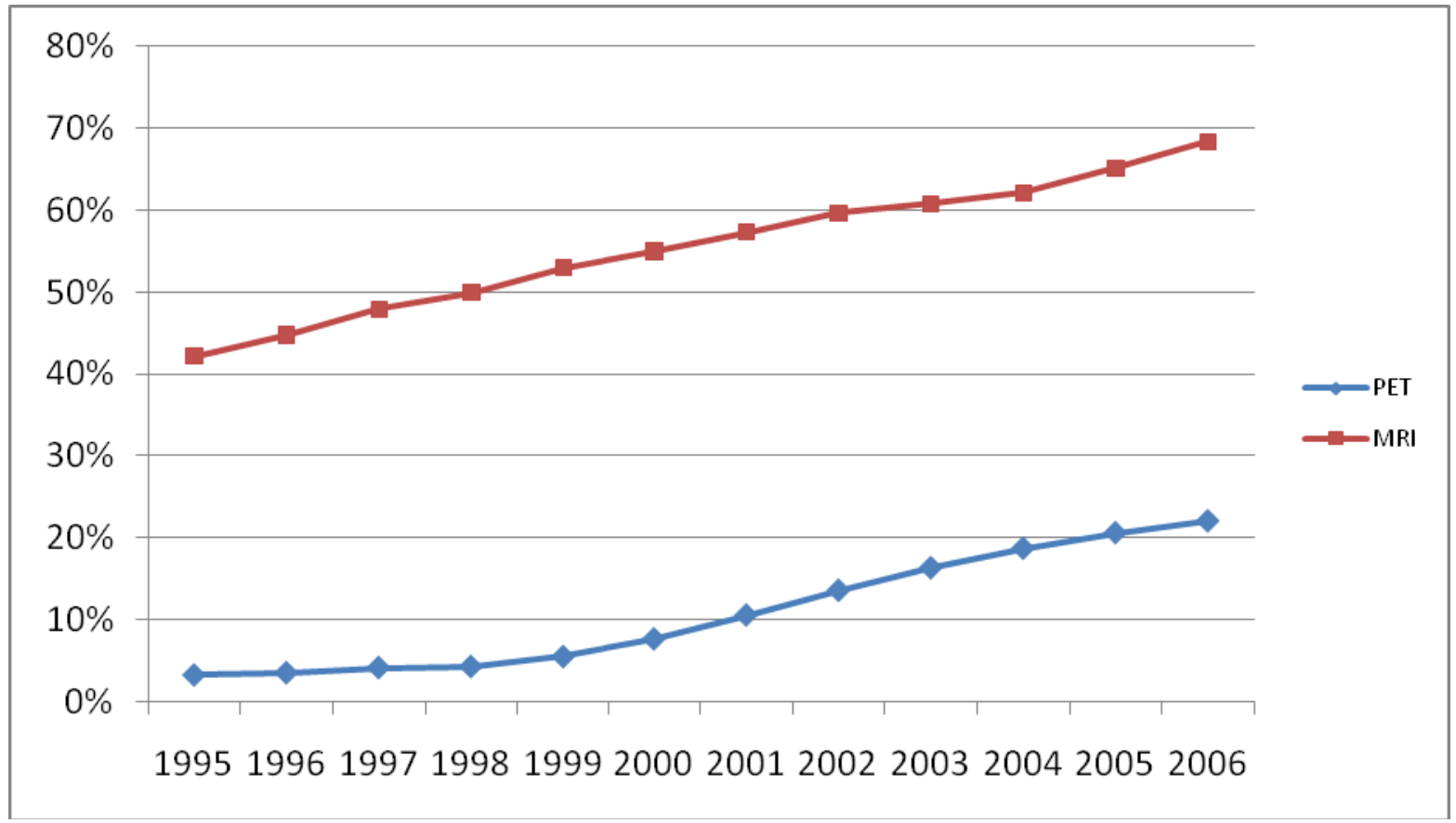

Figure 3: Percentage of hospitals that have invested in PET and MRI imaging technologies 

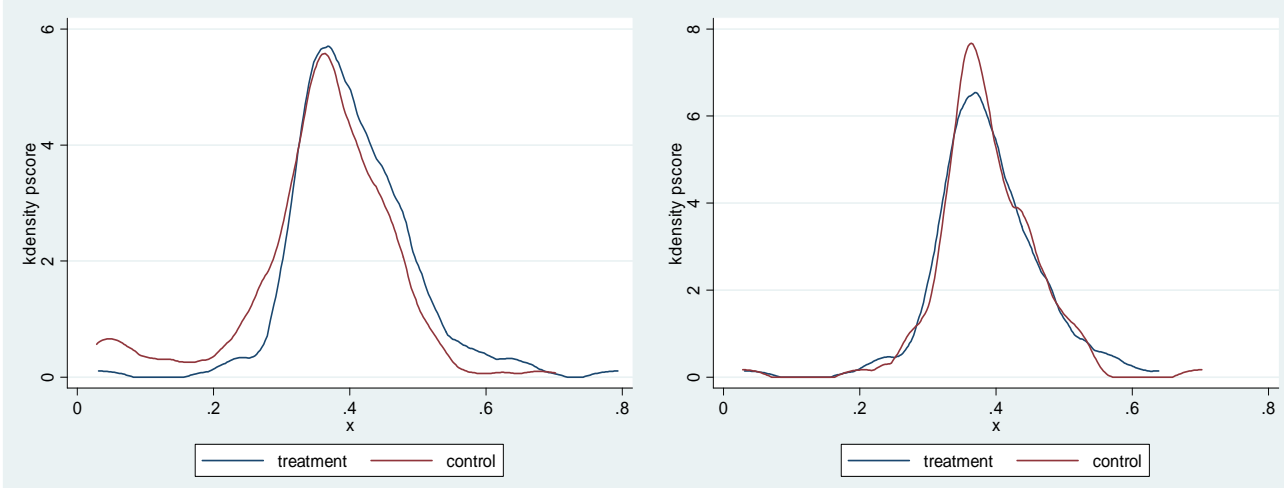

Figure 4: Propensity score of treatment (arm's-length) and control (alliance) groups before and after matching
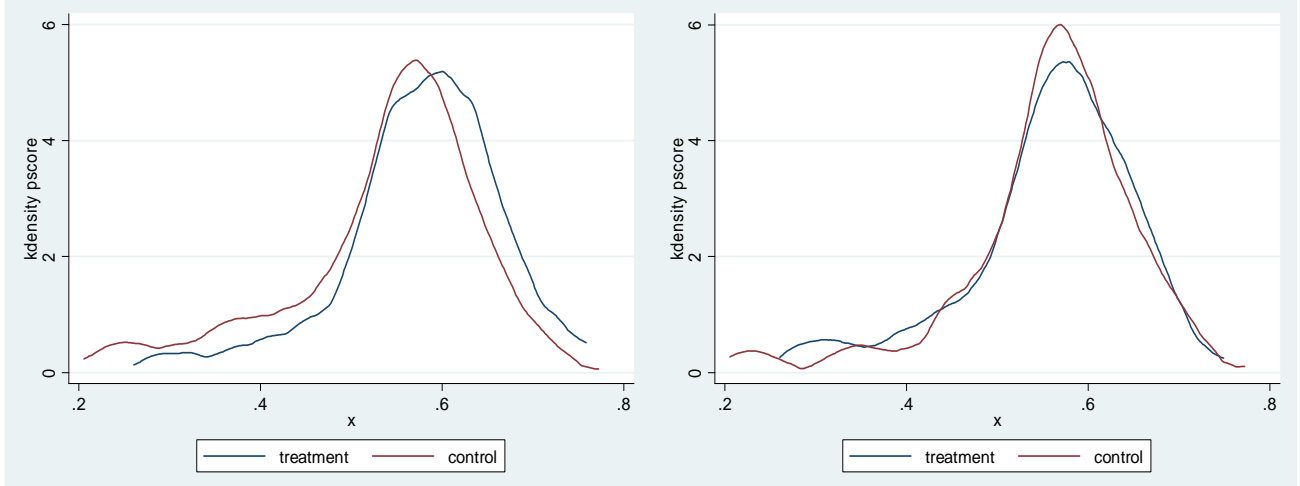

Figure 5: Propensity score of treatment (integrated) and control (alliance) groups before and after matching
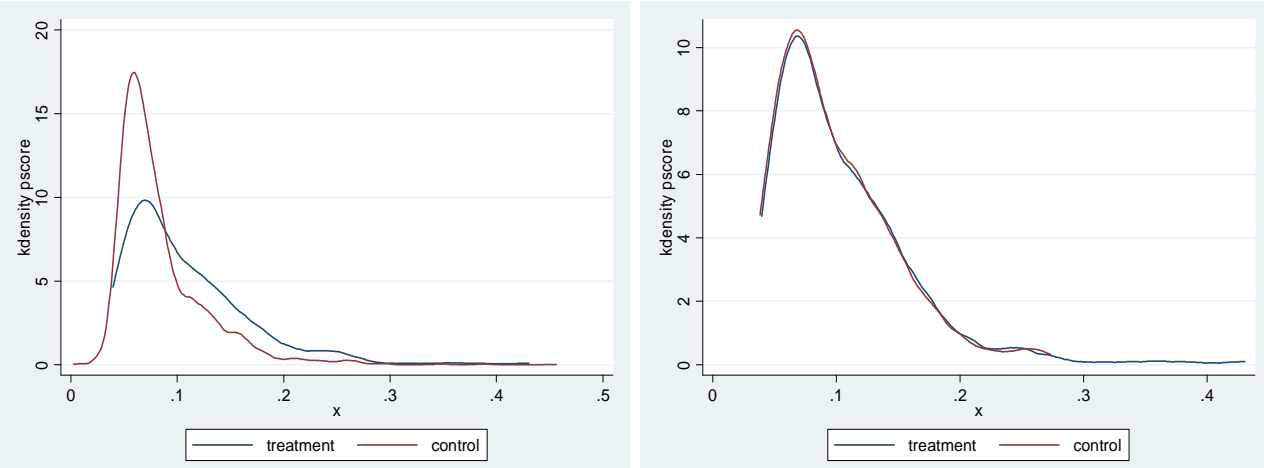

Figure 6: Propensity score of treatment (MCO tapered integration) and control (arm'slength) groups before and after matching 


\section{Table 1: Description of variables}

\begin{tabular}{|c|c|}
\hline Variables & Description \\
\hline \multicolumn{2}{|l|}{ Dependent Variable } \\
\hline Hospital's Technology Investment & Dummy $=1$ for the year the hospital invested in the technology \\
\hline \multicolumn{2}{|l|}{ Independent Variables } \\
\hline Complementor Alliance & Dummy $=1$ for the hospitals that have an alliance relationship with physicians \\
\hline Low Alliance Scope & Dummy $=1$ for the hospitals that use IPA alliance form \\
\hline Medium Alliance Scope & Dummy $=1$ for the hospitals that use OPHO alliance form. \\
\hline High Alliance Scope & Dummy $=1$ for the hospitals that use $\mathrm{CPHO}$ and MSO alliance forms \\
\hline Complementor Integration & $\begin{array}{l}\text { Dummy=1 for the hospitals that have an integrated salary model and employ } \\
\text { physicians }\end{array}$ \\
\hline Buyer (MCO) Tapered Integration & Dummy $=1$ for the hospitals that have an equity relationship with an MCO \\
\hline \multicolumn{2}{|l|}{ Control Variables } \\
\hline \multicolumn{2}{|l|}{ Hospital Effects } \\
\hline Hospital Size & Number of beds in the hospitals \\
\hline Medical School Affiliation & Dummy $=1$ for the hospitals that are members of medical school association \\
\hline Teaching School Member & Dummy $=1$ for the hospitals that are affiliated with teaching school association \\
\hline Not-for-Profit & Dummy $=1$ for the hospitals that are owned by not-for-profit institutions \\
\hline Government Owned & Dummy $=1$ for the hospitals that are owned by the government \\
\hline Outpatient Ratio & $\begin{array}{l}\text { The ratio of total number of annual outpatient visits and the total annual number of } \\
\text { inpatient visits for a given hospital. }\end{array}$ \\
\hline Capacity Utilization & The ratio of hospital's total inpatient days over the number of beds multiplied by 365 \\
\hline \multicolumn{2}{|l|}{ Competitive Effects } \\
\hline Market Concentration & HHI index based on hospital's share of beds in a given county \\
\hline Number of Hospitals & Number of general hospitals in a given county \\
\hline \multicolumn{2}{|l|}{ MCO Effect } \\
\hline MCO Penetration & Dummy $=1$ if Medicare managed care penetration is greater than $15 \%$ \\
\hline \multicolumn{2}{|l|}{ Demand Effects } \\
\hline Unemployment Rate & Unemployment rate in $\%$ for those 16 years and older in a given county \\
\hline Per Capita Income & Per capita income of the county in $0000 \mathrm{~s}$ \\
\hline
\end{tabular}


Table 2: Correlation matrix

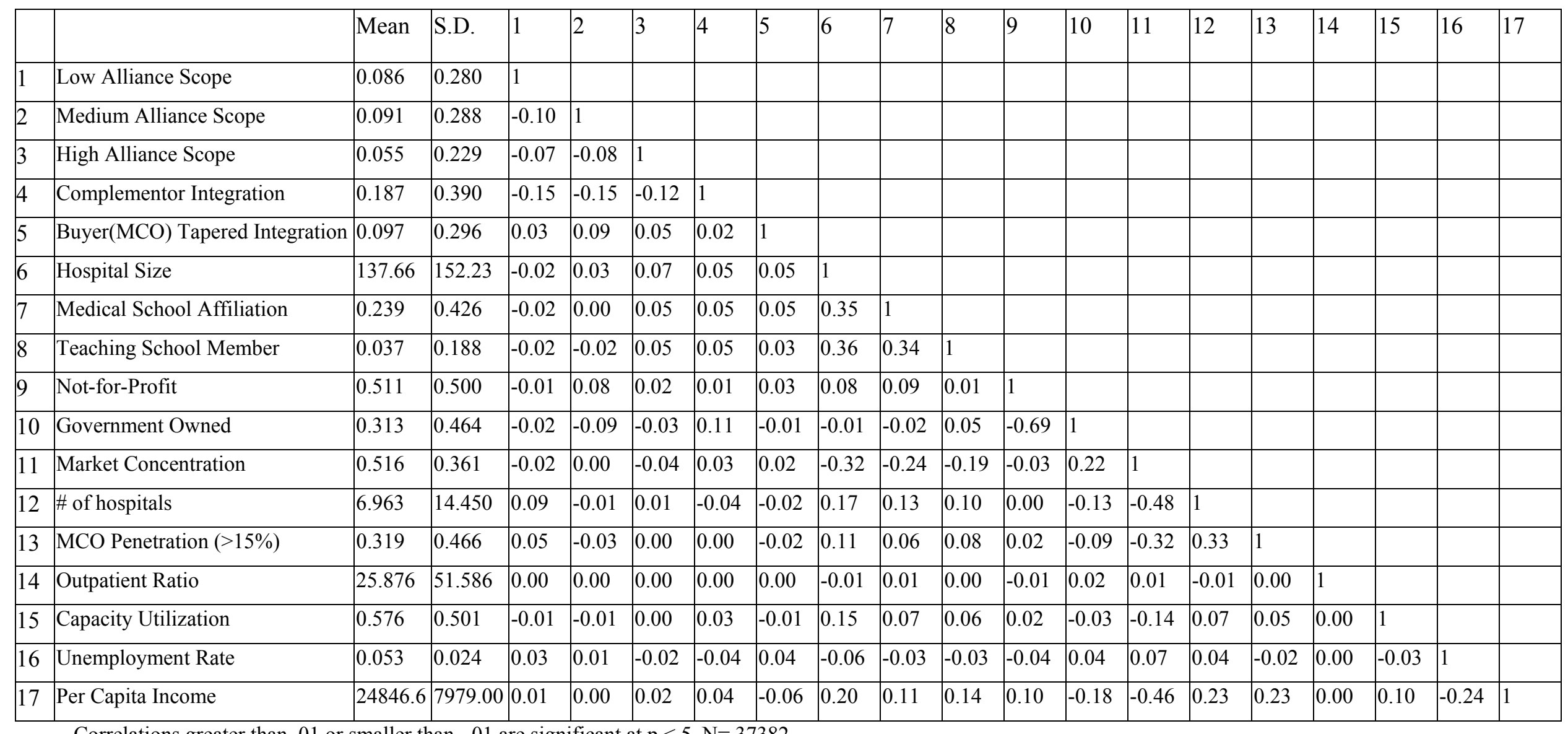

Correlations greater than .01 or smaller than -.01 are significant at $\mathrm{p}<.5, \mathrm{~N}=37382$ 
Table 3: Cox proportional hazards estimates for a hospital's investment into new imaging technology

\begin{tabular}{|c|c|c|c|c|c|c|}
\hline & \multicolumn{3}{|c|}{ PET Technology } & \multicolumn{3}{|c|}{ MRI Technology } \\
\hline & Model 1 & Model 2 & Model 3 & Model 4 & Model 5 & Model 6 \\
\hline \multirow[t]{2}{*}{ Complementor Alliance (H1) } & & $0.228 * * *$ & & & $0.286^{* * *}$ & \\
\hline & & $(0.066)$ & & & $(0.048)$ & \\
\hline \multirow[t]{2}{*}{ Low Alliance Scope } & & & 0.086 & & & $0.193 * * *$ \\
\hline & & & $(0.105)$ & & & $(0.069)$ \\
\hline \multirow[t]{2}{*}{ Medium Alliance Scope } & & & $0.234^{* *}$ & & & $0.239 * * *$ \\
\hline & & & $(0.091)$ & & & $(0.069)$ \\
\hline \multirow[t]{2}{*}{ High Alliance Scope } & & & $0.370 * * *$ & & & $0.501 * * *$ \\
\hline & & & $(0.102)$ & & & $(0.077)$ \\
\hline \multirow[t]{2}{*}{ Complementor Integration } & & 0.042 & 0.043 & & -0.053 & -0.052 \\
\hline & & $(0.079)$ & $(0.079)$ & & $(0.064)$ & $(0.064)$ \\
\hline \multirow[t]{2}{*}{ Buyer Tapered Integration (H4) } & & $0.148^{*}$ & $0.152^{*}$ & & $0.227 * * *$ & $0.234 * * *$ \\
\hline & & $(0.087)$ & $(0.087)$ & & $(0.064)$ & $(0.064)$ \\
\hline \multirow[t]{2}{*}{ Hospital Size } & $0.002 * * *$ & $0.002 * * *$ & $0.002 * * *$ & $0.002 * * *$ & $0.002 * * *$ & $0.002 * * *$ \\
\hline & 0.000 & $(0.000)$ & 0.000 & 0.000 & $(0.000)$ & 0.000 \\
\hline \multirow[t]{2}{*}{ Medical School Affiliation } & $0.287 * * *$ & $0.288 * * *$ & $0.279 * * *$ & $0.426 * * *$ & $0.444 * * *$ & $0.442 * * *$ \\
\hline & $(0.074)$ & $(0.074)$ & $(0.074)$ & $(0.060)$ & $(0.060)$ & $(0.060)$ \\
\hline \multirow[t]{2}{*}{ Teaching School Member } & $0.294 * * *$ & $0.298^{* * *}$ & $0.296^{* * *}$ & $-0.213^{*}$ & $-0.240 * *$ & $-0.249 * *$ \\
\hline & $(0.102)$ & $(0.102)$ & $(0.102)$ & $(0.111)$ & $(0.111)$ & $(0.111)$ \\
\hline \multirow[t]{2}{*}{ Not-for-Profit } & 0.123 & 0.118 & 0.114 & $-0.158 * *$ & $-0.169 * * *$ & $-0.166^{* * *}$ \\
\hline & $(0.090)$ & $(0.090)$ & $(0.091)$ & $(0.064)$ & $(0.064)$ & $(0.064)$ \\
\hline \multirow[t]{2}{*}{ Government Owned } & $-0.268 * *$ & $-0.253^{* *}$ & $-0.254 * *$ & $-0.534 * * *$ & $-0.519 * * *$ & $-0.512 * * *$ \\
\hline & $(0.108)$ & $(0.108)$ & $(0.108)$ & $(0.073)$ & $(0.073)$ & $(0.073)$ \\
\hline \multirow[t]{2}{*}{ Market Competition } & $-0.659 * * *$ & $-0.679 * * *$ & $-0.666 * * *$ & $-0.407^{* * *}$ & $-0.403 * * *$ & $-0.400 * * *$ \\
\hline & $(0.120)$ & $(0.120)$ & $(0.120)$ & $(0.086)$ & $(0.086)$ & $(0.086)$ \\
\hline \multirow[t]{2}{*}{ \# of hospitals } & -0.001 & -0.001 & -0.001 & -0.001 & -0.001 & -0.000 \\
\hline & $(0.002)$ & $(0.002)$ & $(0.002)$ & $(0.002)$ & $(0.002)$ & $(0.002)$ \\
\hline \multirow[t]{2}{*}{ MCO Penetration $(>15 \%)$} & $-0.132 *$ & $-0.120^{*}$ & $-0.122^{*}$ & $-0.146^{* * *}$ & $-0.140 * * *$ & $-0.140 * * *$ \\
\hline & $(0.071)$ & $(0.071)$ & $(0.071)$ & $(0.054)$ & $(0.054)$ & $(0.054)$ \\
\hline \multirow{2}{*}{ Outpatient Ratio } & $-0.004 * * *$ & $-0.004 * * *$ & $-0.004 * * *$ & $-0.006^{* * *}$ & $-0.006 * * *$ & $-0.006^{* * *}$ \\
\hline & $(0.001)$ & $(0.001)$ & $(0.001)$ & $(0.001)$ & $(0.001)$ & $(0.001)$ \\
\hline \multirow[t]{2}{*}{ Capacity Utilization } & $0.0472 * *$ & $0.0480 * *$ & $0.0480^{* *}$ & -0.0229 & -0.0147 & -0.016 \\
\hline & $(0.021)$ & $(0.021)$ & $(0.021)$ & $(0.074)$ & $(0.072)$ & $(0.072)$ \\
\hline \multirow[t]{2}{*}{ Unemployment Rate } & $-0.064 * * *$ & $-0.067 * * *$ & $-0.065^{* * *}$ & $-0.043^{* * *}$ & $-0.044 * * *$ & $-0.043 * * *$ \\
\hline & $(0.017)$ & $(0.000)$ & $(0.017)$ & $(0.011)$ & $(0.011)$ & $(0.011)$ \\
\hline \multirow[t]{2}{*}{ Per Capita Income } & $-0.076^{* *}$ & $-0.087 * *$ & $-0.081 * *$ & $-0.234 * * *$ & $-0.234 * * *$ & $-0.242 * * *$ \\
\hline & $(0.038)$ & $(0.038)$ & $(0.039)$ & $(0.039)$ & $(0.039)$ & $(0.039)$ \\
\hline State Fixed Effects & Yes & Yes & Yes & Yes & Yes & Yes \\
\hline Number of Hospitals & 5367 & 5367 & 5367 & 3947 & 3947 & 3947 \\
\hline Observations & 36833 & 36828 & 36828 & 18919 & 18916 & 18916 \\
\hline Log Likelihood & -10117 & -10109 & -10106 & -17742 & -17704 & -17699 \\
\hline
\end{tabular}

Standard errors in parentheses, ${ }^{* * *} \mathrm{p}<0.01, * * \mathrm{p}<0.05,{ }^{*} \mathrm{p}<0.1$

Our baseline category of hospital-physician governance mode is the arm's-length relationship. 
Table 4: Difference between coefficients estimates using Wald test

\begin{tabular}{|c|c|c|c|}
\hline $\begin{array}{c}\text { PET } \\
\text { Technology }\end{array}$ & Null Hypothesis & Chi $\left.^{\mathbf{2}} \mathbf{2}\right)$ & Prob $>\mathbf{C h i}^{\mathbf{2}}$ \\
\hline H2 & Complementor Alliance = Complementor Integration & 4.76 & 0.029 \\
\hline H3 & Low Alliance Scope = High Alliance Scope & 4.50 & 0.034 \\
\hline
\end{tabular}

\begin{tabular}{|c|c|c|c|}
\hline $\begin{array}{c}\text { MRI } \\
\text { Technology }\end{array}$ & Null Hypothesis & Chi' $\left.^{\mathbf{2}} \mathbf{2}\right)$ & Prob $>\mathbf{C h i}^{\mathbf{2}}$ \\
\hline H2 & Complementor Alliance = Complementor Integration & 24.94 & 0.000 \\
\hline H3 & Low Alliance Scope = High Alliance Scope & 10.52 & 0.001 \\
\hline
\end{tabular}

Table 5: Sample average treatment effect for hospital's investment in the PET technology

\begin{tabular}{|c|c|c|c|}
\hline Hypothesis & $\begin{array}{c}\text { Predicted } \\
\text { Sign }\end{array}$ & Coefficient $^{\mathbf{a}}$ & $\begin{array}{c}\text { Hospitals in } \\
\text { Treatment Group }\end{array}$ \\
\hline $\begin{array}{c}\text { H1 (Complementor Alliance vs. } \\
\text { Arm's-Length) }\end{array}$ & -ve & $\begin{array}{c}-0.068^{* *} \\
(0.039)\end{array}$ & $\begin{array}{c}144 \\
\text { (Alliance to Arm's- } \\
\text { Length) }\end{array}$ \\
\hline $\begin{array}{c}\text { H2 (Complementor Alliance vs. } \\
\text { Integration) }\end{array}$ & $-\mathrm{ve}$ & $\begin{array}{c}-0.062^{* *} \\
(0.036)\end{array}$ & $\begin{array}{c}306 \\
\text { (Alliance to } \\
\text { Integration) }\end{array}$ \\
\hline $\begin{array}{c}\text { H4 (Buyer Tapered Integration } \\
\text { vs. Arm's-Length) }\end{array}$ & $+\mathrm{ve}$ & $\begin{array}{c}0.064^{* *} \\
(0.031)\end{array}$ & $\begin{array}{c}\text { (Arm's-length to } \\
\text { Tapered Integration) }\end{array}$ \\
\hline
\end{tabular}

${ }^{a}$ Sample average treatment effect for the treatment group

${ }^{*}$ Standard errors in parentheses, ${ }^{* * *} \mathrm{p}<0.01,{ }^{* *} \mathrm{p}<0.05,{ }^{*} \mathrm{p}<0.1$ 
Table 6: Probit estimates for a hospital's investment in MRI technology in 1995

\begin{tabular}{|c|c|c|}
\hline & Model 7 & Model 8 \\
\hline \multirow[t]{2}{*}{ Complementor Alliance } & $0.351 * * *$ & \\
\hline & $(0.058)$ & \\
\hline \multirow[t]{2}{*}{ Low Alliance Scope } & & 0.132 \\
\hline & & $(0.089)$ \\
\hline \multirow[t]{2}{*}{ Medium Alliance Scope } & & $0.436 * * *$ \\
\hline & & $(0.082)$ \\
\hline \multirow[t]{2}{*}{ High Alliance Scope } & & $0.518 * * *$ \\
\hline & & $(0.100)$ \\
\hline \multirow[t]{2}{*}{ Complementor Integration } & $-0.160 *$ & $-0.156^{*}$ \\
\hline & $(0.085)$ & $(0.085)$ \\
\hline \multirow[t]{2}{*}{ Buyer (MCO) Tapered Integration } & $0.171^{* *}$ & $0.160^{* *}$ \\
\hline & $(0.067)$ & $(0.067)$ \\
\hline \multirow[t]{2}{*}{ Hospital Size } & $0.00242 * * *$ & $0.00239 * * *$ \\
\hline & $(0.000)$ & $(0.000)$ \\
\hline \multirow[t]{2}{*}{ Medical School Affiliation } & $0.174 * *$ & $0.167 * *$ \\
\hline & $(0.085)$ & $(0.085)$ \\
\hline \multirow[t]{2}{*}{ Teaching School Member } & 0.0273 & 0.0329 \\
\hline & $(0.132)$ & $(0.133)$ \\
\hline \multirow[t]{2}{*}{ Not-for-Profit } & -0.117 & -0.121 \\
\hline & $(0.088)$ & $(0.088)$ \\
\hline \multirow[t]{2}{*}{ Government Owned } & $-0.502 * * *$ & $-0.500^{* * * *}$ \\
\hline & $(0.094)$ & $(0.094)$ \\
\hline \multirow[t]{2}{*}{ Market Competition } & $-0.282 * * *$ & $-0.277 * * *$ \\
\hline & $(0.101)$ & $(0.102)$ \\
\hline \multirow[t]{2}{*}{ \# of hospitals } & $-0.00781 * * *$ & $-0.00722 * * *$ \\
\hline & $(0.002)$ & $(0.002)$ \\
\hline \multirow[t]{2}{*}{ MCO Penetration $(>15 \%)$} & 0.00223 & 0.00769 \\
\hline & $(0.096)$ & $(0.097)$ \\
\hline \multirow[t]{2}{*}{ Outpatient Ratio } & $-0.00661 * * *$ & $-0.00688 * * *$ \\
\hline & $(0.002)$ & $(0.002)$ \\
\hline \multirow[t]{2}{*}{ Capacity Utilization } & 0.164 & 0.142 \\
\hline & $(0.154)$ & $(0.154)$ \\
\hline \multirow[t]{2}{*}{ Unemployment Rate } & $-0.0412 * * *$ & $-0.0423 * * *$ \\
\hline & $(0.013)$ & $(0.013)$ \\
\hline \multirow[t]{2}{*}{ Per Capita Income } & 0.0889 & 0.0747 \\
\hline & $(0.069)$ & $(0.070)$ \\
\hline State Dummies & Yes & Yes \\
\hline Observations & 3298 & 3298 \\
\hline $\mathrm{R} 2$ & 0.1968 & 0.1994 \\
\hline Log Likelihood & -1747.1747 & -1741.4927 \\
\hline
\end{tabular}

Standard errors in parentheses, ${ }^{* * *} \mathrm{p}<0.01,{ }^{* *} \mathrm{p}<0.05,{ }^{*} \mathrm{p}<0.1$ 